\title{
Isotope Production and Irradiation Services Mission Waste Stream Estimates and Management
}

Prepared for the U.S. Department of Energy

Assistant Secretary for Environmental Management

Project Hanford Management Contractor for the

U.S. Department of Energy under Contract DE-AC06-96RL13200

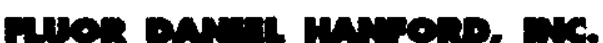

P.O. Box 1000

Richlend, Washington 


\title{
Isotope Production and Irradiation Services Mission Waste Stream Estimates and Management
}

\author{
D.L. Nielsen
}

Fluor Daniel Northwest, Inc.

Date Published

February 1999

Prepared for the U.S. Department of Energy

Assistant Secretary for Environmental Management

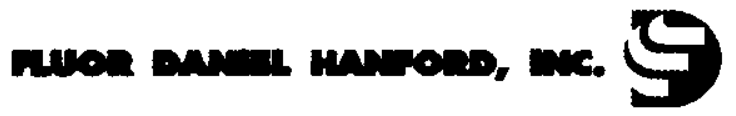

P.O. Box 1000

Richland, Washington 


\section{TRADEMARK DISCLAMMER}

Reference hereln to any specific commercial product, process, or service by trade name, trademark, manufacturer, or othenwise, does not necessarly conatitute or imply its endorsement, recommendation, or favoring by the United States Government or any agency thereof or its contractors or subcontractors.

This report has been reproduced from the best avallable copy. Avallable in paper copy and microfiche.

Available electronically at $h$ ttp://www.doe.gov/bridge. Available for a proceasing foe to the U.S. Department of Energy and its contractors, in paper, from:

U.S. Department of Energy

Office of Scientific and Technical Information P.O. Box 62

Oak Ridge, TN 37831-0062

phone: 865-576-8401

fax: 865-576-5728

email: reporteeadonis.oeti.gov(423) 576-8401

Avallable for sale to the public, in paper, from:

U.S. Department of Commerce

National Technical Information Service

5285 Port Royal Road

Springfield, VA 22161

phone: $800-553-6847$

fax: 703-605-6900

email: orderse ntis. fedworld.gov

online ordertng: http://www.ntis.gov/ordering.htm 


\section{RELEASE AUTHORIZATION}

Document Number:

Document

Title:

HNF-4037, Rev. 0

Isotope Production and Irradiation Services

Mission Waste Stream Estimates and Management

\section{This document, reviewed in accordance with DOE Order 1430.1D, "Scientific and Technical Information Management," and DOE G 1430.1D-1, \\ "Guide to the Management of Scientific and Technical Information," does not contain classified or sensitive unclassified information and is:}

APPROVED FOR PUBLIC RELEASE

Chistive stllixikan

Christine ofillingham

Lockheed Martin Services, Inc.

Document Control / Information Clearance
$12 / 7 / 99$

Dato

Reviewed for Applied Technology, Business Sensitive, Classified, Copyrighted, Export Controlled, Patent, PersonalPrivate, Propribtary, Protected CRADA, Trademark, Unclaseified Controlled Nuclear Intormation.

LEGAL DISCLAIMER. This report was prepared as an account of work sponsored by an agency of the United States Govermment. Nether the United Stutes Government nor any agency thereof, not any of ther employees, nor any of their contractors subcontractors or their employees, makes any warranty, express or impied, or aceumes any legal ilability or responaibilly for the accuracy, complotonces, or any third party's uid of the reaults of such use of any information apparatus, product, or process diedosed, or represents that the use would not infinge privately owned rights. Reforence herein to any

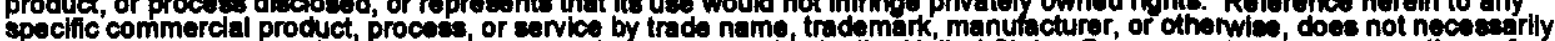

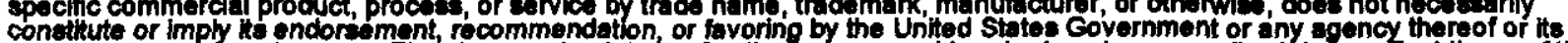
consthute or imply lis endorsement, recommendation, or favoring by the United States Government or any soency thereof or its Untted States Government or any agency thereof. This report has been reproduced from the beet avallable copy. Printed in the Untted States of America. Availibie to the U.S. Department of Energy and lts contractors from the U.S. Department of Energy Oifice of Scientlic and Technical information, P.O. Box 62, Oak Ridos, TN 37831; Telephone: 423i576-8401.

Available to the public from the U.S. Department of Commerce National Technical Information Service, 5285 Port Royal Road, Springfield, VA 22161; Telephone: 703/487-4650. 


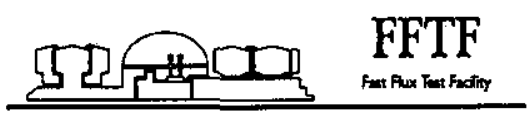

\section{Isotope Production and Irradiation Services Mission Waste Stream Estimates and Management}

\section{Introduction}

The Department of Energy is considering whether to pursue restart of FFTF to concurrently support medical isotope production, Plutonium-238 ( $\mathrm{Pu}-238)$ production and processing, as well as other activities in the areas of power technology, isotope production, space missions, national security, and general nuclear science. Operation of FFTF, and two key support facilities (i.e., the Fuels and Materials Examination Facility (FMEF) and 325 Building), for these proposed missions would necessarily result in the generation of limited waste streams. These wastes would be appropriately managed, treated, and/or packaged into forms that would enable long-term storage or disposal using existing or planned Hanford Site facilities and infrastructure. These waste management activities would be conducted in full compliance with applicable state and federal regulations.

If DOE decides to proceed with consideration of FFTF restart, an Environmental Impact Statement would be prepared. Waste stream management is one of many areas that the EIS would analyze, including the existing Hanford Site waste management capabilities, and cumulative impacts resulting from the proposed activities. This paper provides a brief description of the waste types that would be generated at the FFTF, FMEF and 325 Building and provides projected waste volumes and proposed waste management. Projected volumes associated with FFTF operations are based on historical data and are presented with a high level of confidence. Medical isotope processing estimates are extrapolated from data associated with similar isotope processing activities conducted in the 325 Building. Pu-238 processing is based on extensive studies conducted in 1989 for the conceptual design of a space power system in the FMEF. The projected waste volumes for isotope processing may vary somewhat depending on the isotopes produced and on final processing technology and facility designs. Where detailed information is not yet available, estimates reflect best engineering judgement.

Types of waste that would be generated by the proposed mission activities include: lowlevel radioactive waste, transuranic waste, mixed waste, dangerous waste, and nonhazardous waste. Waste generated from the proposed activities is minimal, especially when compared to annual average quantities of waste similarly handled on the Hanford Site both now or projected over the life of the Hanford Site. The following sections provide waste stream estimates for FFTF, FMEF and 325 Building activities including comparisons to projected total volumes of similarly handled wastes at the Hanford Site. Waste minimization and pollution prevention practices are an active and ongoing effort at the Hanford Site and would be incorporated early in the mission planning to determine if alternative processes and technologies could accomplish still further reductions in the generation of wastes. 


\section{Isotope Production and Irradiation Services Mission Waste Stream Estimates and Management}

\section{Summary}

The composite projected radioactive waste streams for the proposed mission and corresponding comparisons with projected Hanford Site inventories from other sources are depicted below. In all cases, the waste additions from the proposed mission are well within the error bands of the projected waste volumes from other Hanford sources. Therefore the proposed FFTF mission will have insignificant impact on any aspect of Hanford cleanup.

\section{Liquid Low-Level Radioactive Waste (gallons per year)}

FFTF Operations

Pu-238 Processing

Medical Isotope Processing (mixed waste)

Mission Subtotal

$\%$ Increase from FFTF Proposed Mission

Liquid Transuranic Waste (gallons generated over mission lifetime)

FFTF Operations

Pu-238 Processing

Medical Isotope Processing

Mission Subtotal

Current Hanford Inventory (excluding new waste stream contributions)

$\%$ Increase from FFTF Proposed Mission

$$
\begin{array}{r}
30,000 \\
0 \\
30,000 \\
54,000,000
\end{array}
$$

0.1

Solid Low-Level Radioactive Waste (cubic meters per year)

FFTF Operations

Pu-238 Processing ${ }^{*}$

Medical Isotope Processing (mixed waste)

Mission Subtotal

Hanford Projections (all programs)

$\%$ Increase from FFTF Proposed Mission

Spent Nuclear Fuel "* (metric tons heavy metal generated over mission lifetime)

FFTF Operations

Current Hanford Inventory (all programs)

2,133

$\%$ Increase from FFTF Proposed Mission

\footnotetext{
- Includes 0.5 cubic meters of transuranic waste and 0.5 cubic meters of mixed waste.

** Although not a waste, spent nuclear fuel is included for completeness.
} 


\section{Isotope Production and Irradiation Services Mission Waste Stream Estimates and Management}

\section{FFTF}

The proposed mission for FFTF would consist of activities very similar to those conducted during the previous 10 years of reactor operation. Unirradiated fuel and isotope targets would be received at FFTF for irradiation in the reactor. During outages, the reactor would be refueled, selected targets removed, and routine preventative maintenance activities conducted. Fuel and targets would be handled in the same manner as fuel and other test components were handled

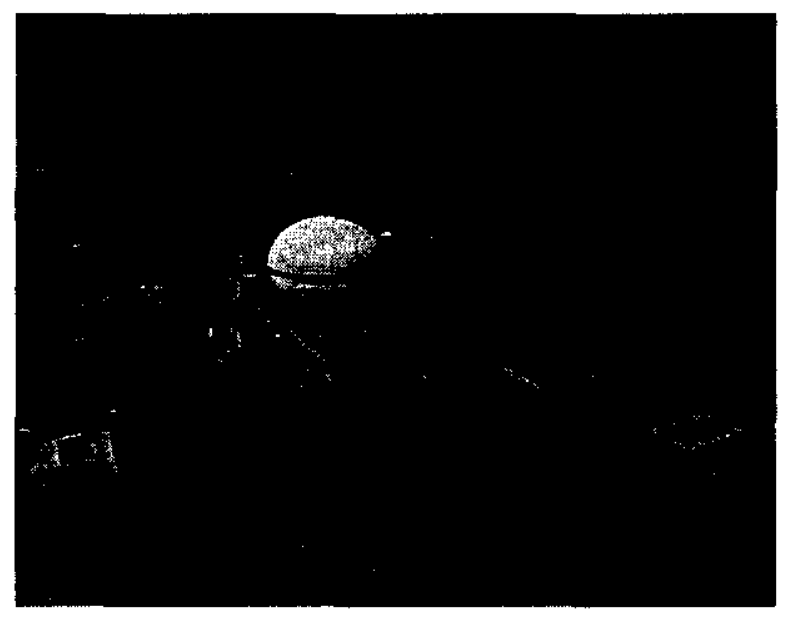
during previous FFTF operations. The following projected waste volumes reflect conservative estimates and are based on historical waste volumes generated during reactor operation. Each category of waste is described, the projected volumes, and a brief synopsis of the management/disposition path.

\section{Liquid Low-Level Radioactive Waste (1500 gallons per year projected)}

During the previous 10 years of reactor operation, approximately 5800 gallons of lowlevel liquid waste was generated each year, primarily in conjunction with the removal of residual sodium from reactor components before disassembly or test processing. In addition, approximately 1000 gallons of wastewater each year was generated at the Maintenance and Storage Facility (MASF) as a result of decontamination and maintenance activities. MASF is located approximately 500 feet north of the FFTF complex and provides the capability for decontamination, repair, and storage of nonfuel components and hardware for FFTF. In 1995, an ion exchange system was added to the FFTF sodium removal system to allow reuse of the wash water, thus reducing the total quantity of water generated by FFTF. Approximately 1500 gallons per year are projected if FFTF restarts to support the proposed mission. For comparison, the Operational Waste Volume Projection Report (HNF-SD-WM-ER-029, Rev. 24), estimates that an annual average of approximately 190,000 gallons of liquid waste will be generated at the Hanford Site through the year 2015. The additional FFTF low-level liquid waste would represent less than one percent of this projected volume.

Liquid low-level waste would be transported from the 400 Area directly to the Effluent Treatment Facility in the 200 East Area (Figure 1) using an existing Department of Transportation certified tanker truck currently owned and operated by the Effluent Treatment Facility. The Effluent Treatment Facility processed 30 million gallons in 


\section{Isotope Production and Irradiation Services Mission Waste Stream Estimates and Management}

1998, and is expected to continue at or near this rate for processing the new vitrification facility low-level liquid waste over its lifetime. Again, the FFTF contribution during this period would be insignificant.

\section{Figure 1}

\section{Effluent Treatment Facility}

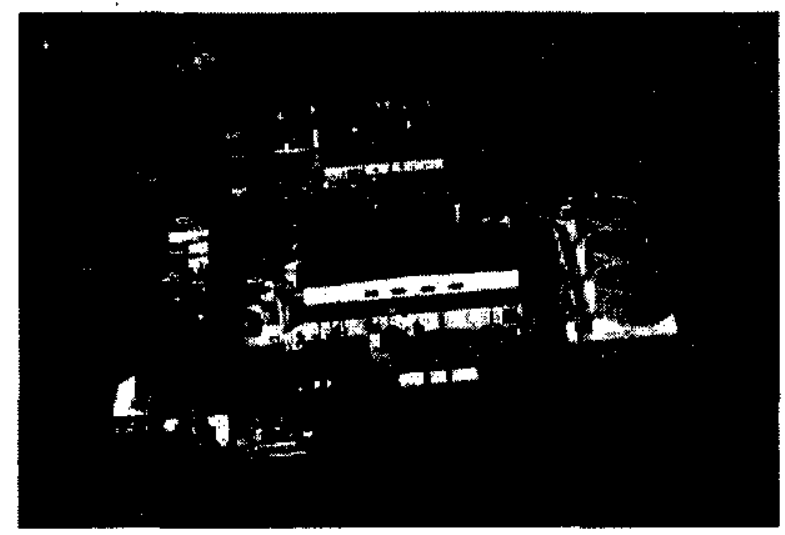

The 200 Area Effluent Treatment Facility is a non-nuclear facility that provides treatment and disposal of 242-A evaporator process condensate effluent, waste liquid that is stored in the Liquid Effluent Retention Facility, and aqueous waste water containing low specific activity. The Effluent Treatment Facility includes an effluent collections system, a continuous treatment system, and a disposal system. The principal features of the facility consist mainly of a large effluent surge tank, a treatment and process building, three large verification tanks for liquid effluent, and supporting structures. The facility began operation in December 1995 and has a 30-year design life. It is capable of processing 150 gallons per minute of liquid waste.

\section{Solid Low-Level Radioactive Waste (LLW) (80 cubic meters per year projected)}

The average amount of solid low-level waste generated during the years of reactor operation was approximately 27 cubic meters per year. (As a reference point, one cubic meter equals approximately five 55 gallon drums.) If FFTF restarts, it is estimated that approximately 80 cubic meters of waste would be generated due to disassembly of isotope hardware, disposal of spent non-fueled reactor components, and spent ion exchange resin (this volume includes the disposal casks). Solid low-level waste is packaged in appropriate containers or burial casks and sent to the 200 Area low-level burial grounds for disposal (Figure 2). For comparison, the Solid Waste Integrated Forecast Technical Report: FY 1999 to FY 2046 estimates that an annual average of approximately 4,400 cubic meters of low level solid waste will be generated at the Hanford Site between FY 1999 and FY 2046. The additional FFTF low-level waste 


\section{Isotope Production and Irradiation Services Mission Waste Stream Estimates and Management}

would represent approximately two percent of this projected volume, well within the uncertainty band between forecasted volumes and volumes actually received.

Figure 2

\section{Hanford Site Burial Grounds}

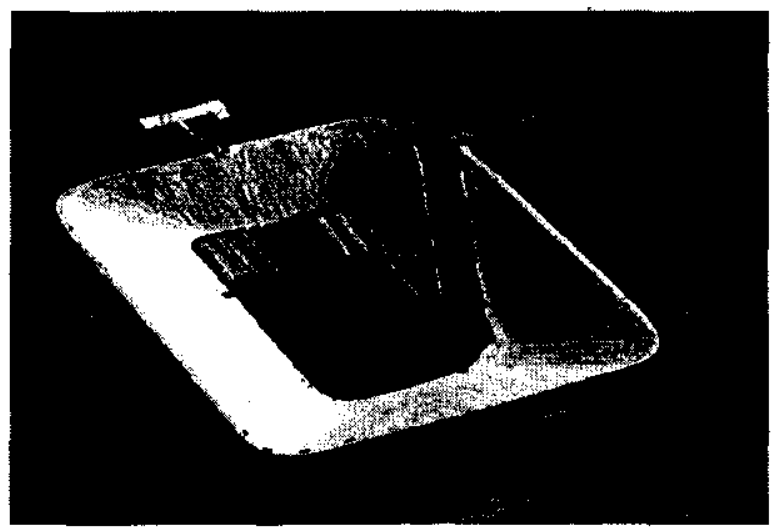

The low-level burial grounds are located in the 200 Area of the Hanford Site providing for controlled burial of low-level radioactive waste. The burial grounds include a number of unlined disposal trenches that accept low-level radioactive waste that has met acceptance criteria. The burial grounds also include two lined trenches for disposal of low-level mixed waste.

\section{Dangerous Waste}

Dangerous waste is solid waste regulated as dangerous, extremely hazardous, or mixed (radioactive) waste under Chapter 173-303, of the State of Washington Administrative Code (WAC), "Dangerous Waste Regulations," and the Hanford (site wide) Facility RCRA Permit. Approximately 4 cubic meters of dangerous waste will be generated annually. This estimate is based on average amounts of dangerous waste generated during the years of past reactor operations. Typical dangerous wastes generated at FFTF include spent solvents, ethylene glycol, paint-related wastes, and cutting fluids from maintenance activities. Whenever possible, waste materials are recycled as product for reuse, rather than disposed of as dangerous waste. All dangerous wastes are shipped to off site RCRA treatment, storage and disposal (TSD) facilities for processing.

\section{Industrial Process Wastewater}

Groundwater, pumped from wells on site, is used for cooling non-radiological systems (common industrial cooling systems such as air conditioners and heat pumps). Under the State of Washington Waste Discharge Permit No. ST-4501, FFTF is authorized to return the process wastewater to the ground via two evaporation/percolation ponds located immediately northeast of the 400 Area northern fenced boundary. In accordance with 


\section{Isotope Production and Irradiation Services Mission Waste Stream Estimates and Management}

permit requirements, the industrial process wastewater is periodically sampled to monitor compliance with permit conditions and discharge limits, thus ensuring that applicable federal and state water quality standards are maintained. For the proposed mission, the projected process wastewater is approximately 35 to 60 gallons per minute, however, no new contaminants would be introduced. The water will continue to be returned to the ground with essentially the same water quality as when pumped from the wells.

Figure 3

400 Area Process Wastewater System

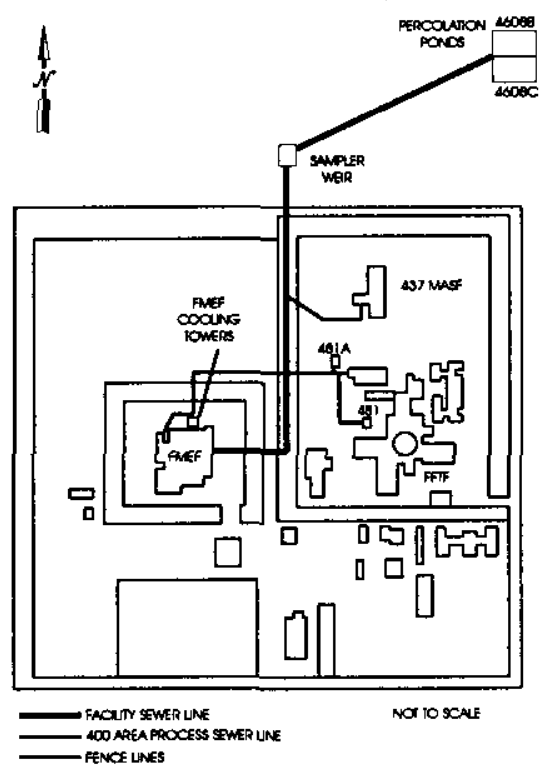

The 400 Area process waste water system receives effluents from four facilities located in the 400 Area: FMEF, MASF, the water pump house, and the FFTF cooling towers. The effluent wastewater generated in the four facilities enters the 400 Area process drain through five 6 -inch diameter facility process drain lines. The effluent stream is monitored before discharge to the percolation ponds. The unlined ponds are typically dry as the water quickly seeps into the earth. The discharges are regulated by State Waste Discharge Permit ST -4501.

\section{Sanitary Wastewater}

In October 1996, RL signed an agreement with the Washington Public Power Supply System (now called Energy Northwest) to allow the 400 Area sanitary wastewater effluent to be discharged to the Washington Public Power Supply System via an existing tie line. This discharge began in April 1997. The Energy Northwest sanitary wastewater discharge and treatment system is regulated under the State of Washington Energy Facility Site Evaluation Council Resolution No. 259. For the proposed mission, the projected sanitary wastewater is approximately 15,000 gallons per day. 


\section{Isotope Production and Irradiation Services Mission Waste Stream Estimates and Management}

\section{Spent Nuclear Fuel (15 assemblies per year projected)}

Spent nuclear fuel is regulated by the federal Atomic Energy Act of 1954, and is not considered a waste per the Act's definition. Operation of the FFTF for the proposed mission at 100 megawatts is expected to generate on the order of 15 spent fuel assemblies annually (operation at full power capacity [i.e., 400 megawatts] would generate 60 spent fuel assemblies annually). Assuming a 30-year mission, operation at 100 megawatts would result in approximately 15 metric tons heavy metal of spent nuclear fuel being added to the DOE inventory. For perspective, this corresponds to less than 1 weight percent of the total spent nuclear fuel inventory currently stored at the Hanford Site.

Current planning for the existing FFTF spent fuel calls for short-term storage in interim storage casks at the 400 Area Interim Storage Area (Figure 4) with planned future relocation of the casks to the interim storage area at the Canister Storage Building complex (the concrete pads can be seen in Figure 5) until availability of a permanent repository for disposal. The Interim Storage Casks were designed for onsite transport. This planning basis would be expanded to include new spent fuel that would be generated from the proposed mission until the national geologic repository is available. Each interim storage cask contains up to seven fueled components, therefore approximately two casks per year would be required.

Figure 4

400 Area Interim Storage Area

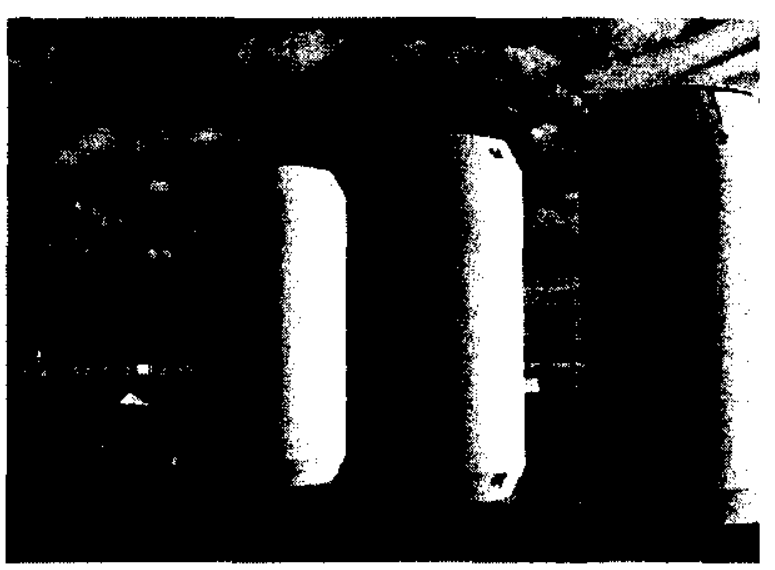

The 400 Area Interim Storage Area is located adjacent to the FFTF at the far northeast corner of the 400 Area. This location consists of a 513 feet by 247 feet totally fenced area with perimeter lighting that is designated for aboveground dry cask storage of spent fuel. The fenced area is locked to limit access. An existing concrete pad, which measures 90 feet by 120 feet, is used for storage of the spent fuel casks. 


\section{Isotope Production and Irradiation Services Mission Waste Stream Estimates and Management}

\section{Figure 5 \\ 200 Area Canister Storage Building Complex}

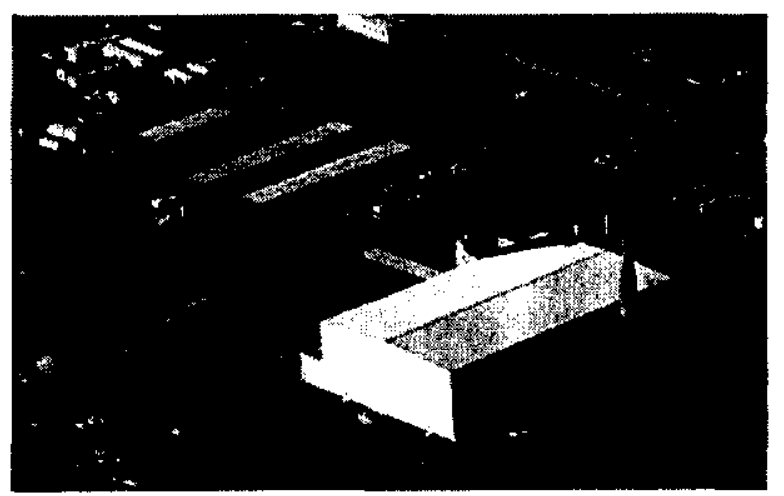

The Canister Storage Building complex is located in the 200 East Area and will be used to provide consolidated storage of the Hanford Site non-defense production reactor spent nuclear fuel.

\section{FMEF}

DOE is evaluating re-establishment of a reliable domestic capability for producing $\mathrm{Pu}-238$ for space mission requirements. A $\mathrm{Pu}-238$ production rate of $2-5$ kilograms per year for approximately 30 years would be sufficient to meet the projected longterm user requirements. FMEF is a candidate site for storage of neptunium237 , fabrication of targets, and processing of irradiated targets. Detailed studies were conducted in the late 1980's on

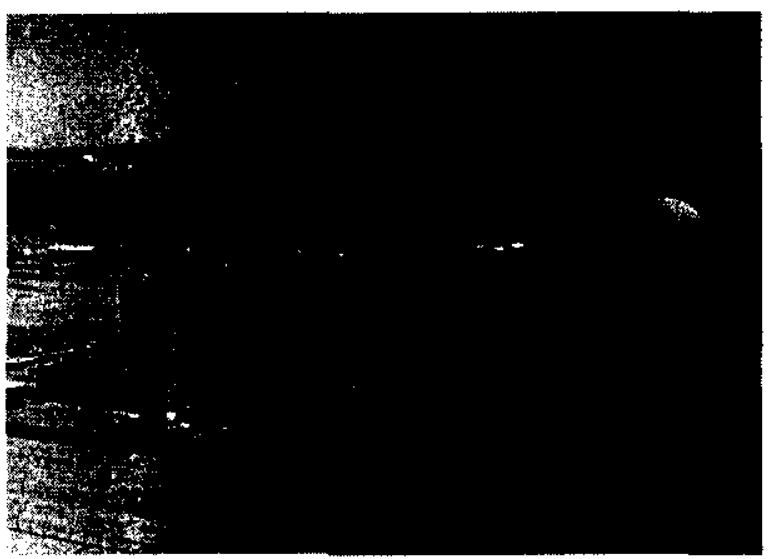
establishing a reliable source of Pu-238 in support of both NASA and Department of Defense missions. A conceptual design report was prepared in 1990 to install a space power systems facility in the FMEF to process $\mathrm{Pu}-238$ from neptunium-237 targets irradiated at FFTF. These earlier studies focused on production of 30 kilograms of Pu238 per year. The following waste stream projections are scaled down from estimates and assumptions provided in these earlier studies to reflect the decrease in production rate from 30 kilograms to 5 kilograms. 


\section{Isotope Production and Irradiation Services Mission Waste Stream Estimates and Management}

\section{Liquid Low-Level Radioactive Waste (500 gallons per year projected)}

The FMEF radioactive liquid waste system consists of two tanks and associated radiation, liquid level, pressure, and flow monitoring equipment. These tanks would be used for collecting the low-level radioactive liquid waste generated by equipment and systems such as the hot repair room ultransonic cleaner, retention waste system monitored tanks, floor drains in contaminated areas, low-level process liquid wastes, personnel decontamination areas, and truck-lock area drains. The volume of waste is expected to be less than 500 gallons per year for the reduced production rate. This waste would be either transported to the Effluent Treatment Facility in the 200 E Area (Figure 1) using the existing Department of Transportation certified tanker truck currently owned and operated by Effluent Treatment Facility or alternatively transported to the 242-A Evaporator (Figure 6).

Figure 6

\section{2-A Evaporator}

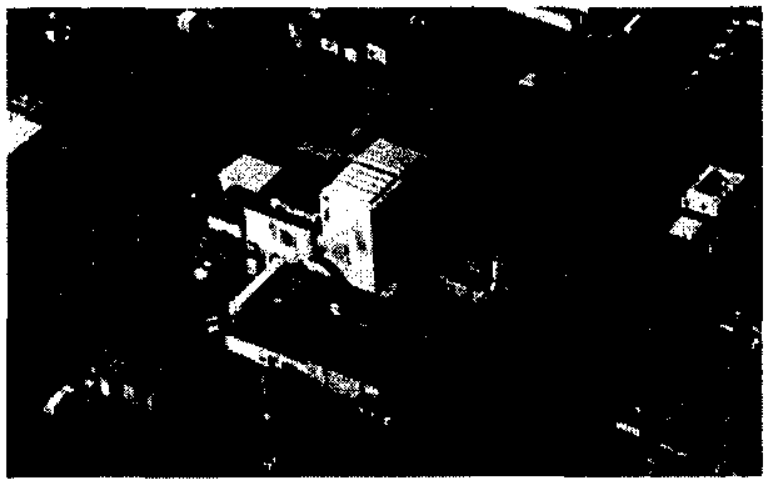

The 242-A Evaporator is a nuclear facility used to reduce the volume of dilute waste solutions, which in tum reduces the number of underground Double Shell Tanks required for waste storage. The evaporator process employs a conventional forced circulation, vacuum evaporation system to concentrate radioactive waste solutions.

\section{Transuranic Liquid Waste (30,000 gallons over the mission lifetime projected)}

Approximately 1000 gallons per year of remote-handled liquid containing fission product would be produced from ion exchange column operations. This remote-handled liquid would be transported to the 200 Area tank farms or possibly received directly at the vitrification plant. Over the 30 year life of the $\mathrm{Pu}-238$ project, approximately 30,000 gallons of remote-handled liquid could be generated. For perspective, this contribution represents 0.06 percent of the current Hanford high level waste tank volume (i.e., 54 million gallons). This excludes the contribution from other Hanford transuranic liquid waste streams over the project life. 


\section{Isotope Production and Irradiation Services Mission Waste Stream Estimates and Management}

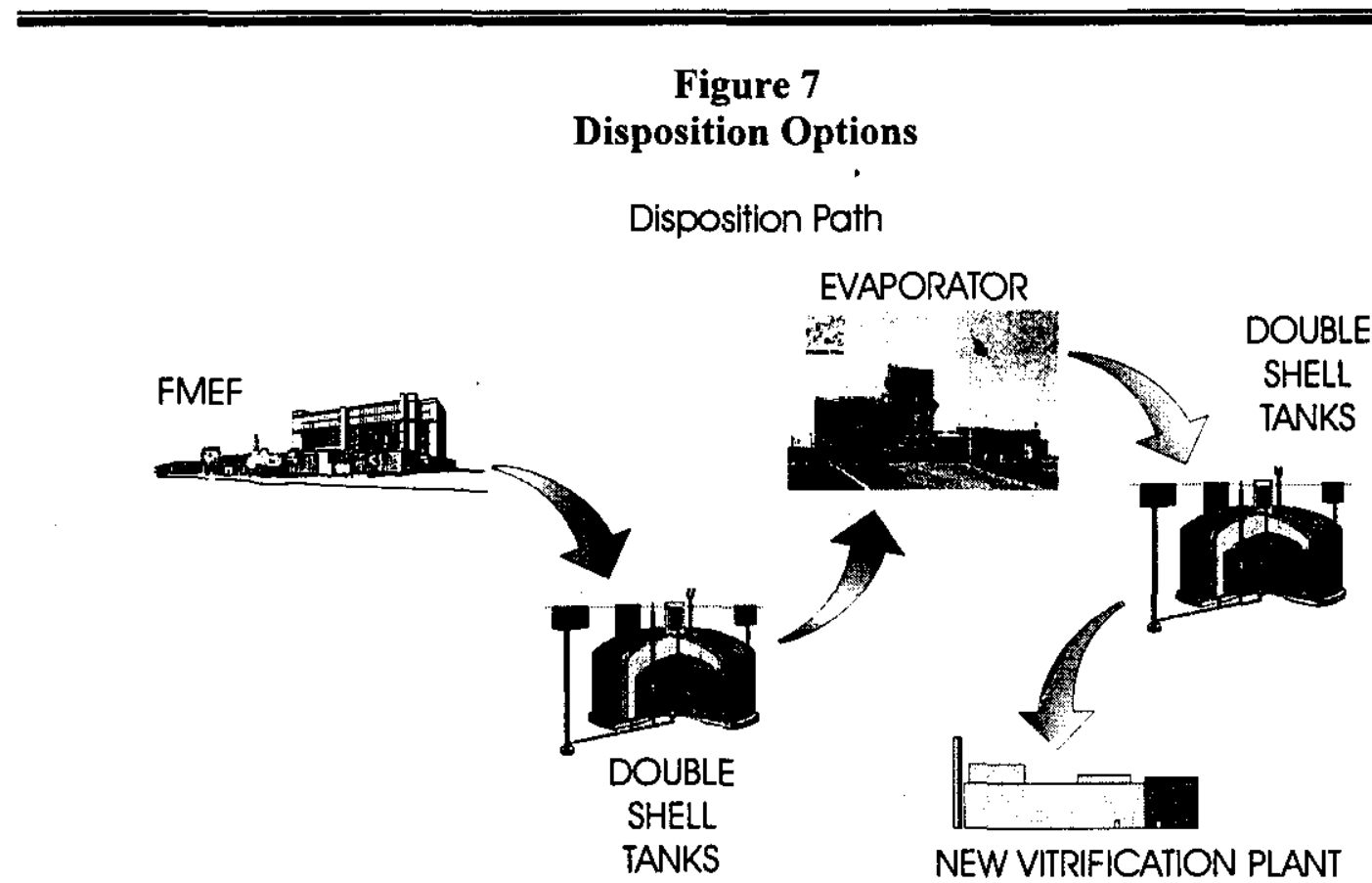

\section{Solid Low-Level Radioactive Waste (10 cubic meters per year projected)}

Solid waste would be generated during the $\mathrm{Pu}-238$ processing activities and in support of facility and process maintenance. This would include wastes such as filters, highefficiency particulate air filters, and failed equipment. This waste would be compacted, if possible, and packaged into containers and shielded disposal containers, as appropriate. It is assumed that less than 10 cubic meters of low-level waste would be generated as a result of these activities and that half of this amount ( 5 cubic meters) would be remotehandled waste. All low-level waste leaving the facility would be examined and nondestructively assayed to determine if there is TRU contamination or special nuclear material present. The waste would be transported to the 200 Area burial trenches or it would be transferred to the 200 Area Waste Receiving and Processing (WRAP) facility (Figure 8) for interim storage/processing prior to permanent disposal at the Waste Isolation Pilot Plant (WIPP) in New Mexico. 


\section{Isotope Production and Irradiation Services Mission Waste Stream Estimates and Management}

Figure 8

WRAP

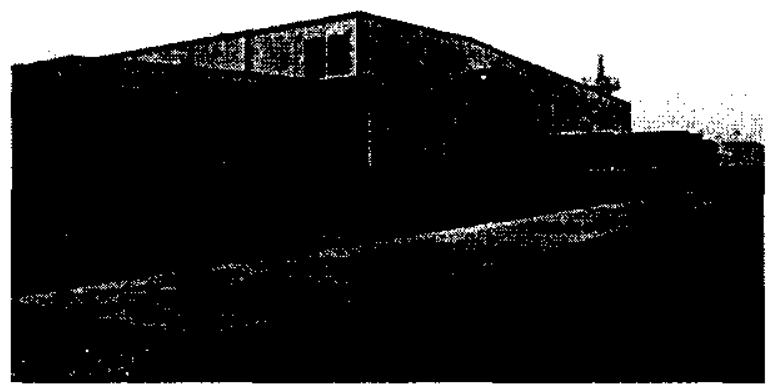

The Waste Receiving and Processing Facility receives waste containers for verification, sampling, treatment and repackaging. It is specifically designed to prepare transuranic wastes for shipment to the Waste Isolation Pilot Plant. Managed waste could also be sent to other Hanford Site facilities for treatment, storage and/or disposal.

\section{Transuranic Solid Waste}

A small in-cell solidification system would be used to solidify high-activity wastes generated within the hot cell such as spent resin. The solidified mixture would be checked and certified to WIPP waste acceptance criteria, sealed, and transferred to a shielded cask for shipment to the 200 Area for interim storage prior to permanent disposal at the WIPP facility. It is anticipated that less than 0.5 cubic meters per year of this waste would be generated. For comparison, the Solid Waste Integrated Forecast Technical Report: FY 1999 to FY 2046 estimates that an annual average of approximately 200 cubic meters of transuranic solid waste will be generated at the Hanford Site between FY 1999 and FY 2046. The additional FMEF contribution represents approximately 0.25 percent of this projected volume.

\section{Solid Mixed Waste}

Less than 0.5 cubic meters per year of mixed low level waste would be generated from activities associated with the analytical chemistry operations in the facility. This waste would be appropriately packaged and transported to the 200 Area for disposal. Two lined burial trenches are available for disposal of acceptable mixed low level waste (Figure 2). 


\section{Isotope Production and Irradiation Services Mission Waste Stream Estimates and Management}

\section{Dangerous Waste}

Less than 0.5 cubic meters of dangerous waste (as defined by Washington Administrative Code 173-303) would be generated each year from routine maintenance activities. Sources of these wastes could include spent pump oils, hydraulic fluid, laboratory solvents, cleaning solvents, etc. Waste would be reused, recycled, or appropriately packaged and managed as regulated waste. The Hanford Site manages nonradioactive dangerous waste through direct shipments to offsite contractors.

\section{Building}

Irradiated medical isotopes would be transported from FFTF to the 325 Building for processing, packaging and shipment of the product isotopes. Chemical separation techniques would be used to extract and purify the medical isotopes. The type of process used would depend on the particular isotope being produced. The 325 Building is a research facility that has been operating for more than 40 years in support of process research development and demonstration, analytical chemistry research and services, and treatment of radioactive, dangerous, or mixed waste. Receipt, processing, and chemical separation, and purification of product medical isotopes is an activity that has been conducted routinely at the 325 Building during previous FFTF operation (albeit, not on the scale proposed by the new mission). The associated medical isotope waste products would represent a small percentage increase $(\sim 4 \%)$ to the total waste currently generated at the 325 Building.

\section{Mixed Waste}

Approximately 20 gallons of liquid mixed waste would be generated each year and temporarily stored in the 325 Building. The waste would be transported by an approved shipping container to a waste treatment/storage facility located in the 2.00 Area.

Approximately 4 cubic meters of solid mixed waste would be generated each year during the processing activities and in support of facility and process maintenance. This could include wastes such as filters, spent ion exchange resin, high-efficiency particulate air 


\section{Isotope Production and Irradiation Services Mission Waste Stream Estimates and Management}

filters, and failed equipment. This waste would be packaged into appropriate containers and transported to the 200 Area for storage/disposal.

\section{Dangerous Waste}

Less than 1 cubic meter of dangerous waste (as defined by Washington Administrative Code 173-303) would be generated each year from routine maintenance activities. Sources of these wastes could include spent pump oils, hydraulic fluid, laboratory solvents, cleaning solvents, etc. Waste would be reused, recycled, or appropriately packaged and managed as regulated waste. The Hanford Site manages nonradioactive dangerous waste through direct shipments to off-site contractors.

\section{Conclusion}

The attached table provides a summary of the waste volumes and planned disposition for wastes generated by the proposed FFTF mission. Waste generated from the proposed activities is minimal, especially when compared to average quantities of waste similarly handled on the Hanford Site, both now or projected over the life of the Hanford Site. In all cases, the FFTF mission contributes only an incremental increase to the waste volumes projected for the Hanford Site. This additional waste could be readily accommodated by the current waste management infrastructure without impacting current Hanford Site cleanup schedules. 